\title{
Adoption of Mobile Technology Application at a Technical University in Ghana
}

\author{
Noble Arden Kuadey \\ Ho Technical University (HTU) \\ Department of Computer Science \\ Francois Mahama \\ Ho Technical University (HTU) \\ Dept. of Mathematics and Statistics
}

\author{
Lily Bensah \\ Ho Technical University (HTU) \\ Department of Computer Science \\ Victor Kwaku Agbesi \\ Uni. of Elec. Sci. and Tech. of China (UESTC) \\ Sch. of Computer Science and Engineering
}

\author{
Carlos Ankora \\ Ho Technical University (HTU) \\ Department of Computer Science \\ Newman Kpogo Newman \\ Valley View University (VVU) \\ Department of Computer Science
}

\begin{abstract}
This study seeks to examine determinants that can influence students intention to use a mobile technology application. To examine these determinants, this study adopted mobile service acceptance model that have constructs such as context, personal characteristics and initiatives, trust, perceived usefulness, perceived ease of use and intention to use. A sample of 170 students from Ho Technical University (HTU) experimented with HTU GPA mobile technology application after which a questionnaire was administered. Partial least square structural equation modeling (PLSSEM) was used in analyzing data that was collected. The results from the study showed that trust, perceived usefulness and perceived ease of use have significant effect on students intention to adopt HTU GPA mobile technology application. Trust had the most significant effect on students intention to adopt the mobile technology application. Context had significant effect on perceived usefulness and perceived ease of use which indirectly influenced students intention to adopt the application. The results from this study provide both researchers and practitioners insights into determinants that impact students adoption of mobile technology application in a university. For researchers, this study contributes to existing literature on intention of students to adopt a mobile technology application while for practitioners it helps them gain a better insight into what key features to consider during the design and development of mobile technology applications.
\end{abstract}

\section{General Terms}

Mobile application, mobile learning, mobile service adoption

\section{Keywords}

Adoption, Determinants, Mobile Service Acceptance Model, Mobile Technology Application, University

\section{INTRODUCTION}

Mobile technology has greatly increased across the globe and it is estimated that about 5 billion people own mobile devices [1]. In [2], a survey was conducted among undergraduate students in 195 higher education institutions on ownership of technology, use patterns and their perceptions of technology. In their findings, $62 \%$ of the students own smartphone and about $85 \%$ of them have used their devices to check their grades. Kobus et al. [3] conducted a study which showed that $67.9 \%$ of Dutch university students own a smartphone. Similarly, Farley et al. [4] conducted a study at a university in Australia which showed that $90 \%$ of the students own smartphones. Furthermore, Addo [5] conducted a study which showed that $93 \%$ of students in higher education in Ghana use mobile phones. In [6], a study conducted showed that $98.7 \%$ of distance education students in a Ghanaian university had mobile phones. Similarly, Edumadze et al. [7] conducted a study on students perception of adoption of mobile learning in a Ghanaian university. In their study, $97.2 \%$ of students either use smart phone or tablet PC. Students who own mobile devices are quite common on various campuses of higher institutions [8]. Prior researchers have shown growth of students owning mobile devices on various campuses of higher institutions. Thus, Industry players in mobile technologies can leverage on students owning mobile devices to develop mobile technology applications that can support their education. However, full benefits of mobile technology applications developed to support students education depend on their adoption of such applications. Therefore, students involvement and adoption of mobile technology applications must be considered. Thus, it is important to identify determinants that will have effect on students adoption of mobile technology application. Several studies [9.-14] that seek to examine end-users intention to adopt a technology have been conducted. However, studies that examine determinants that influence the intention of students to adopt a mobile technology application in higher education have not been sufficiently addressed especially in the Ghanaian higher education context [15]. In addition, studies conducted by $[16-19]$ showed that there are still challenges in acceptance of mobile learning system. Therefore, this study seeks to examine determinants that will lead to adoption of mobile technology application by students in a higher education in Ghana.

The remaining sections in this paper is structured as follows: Theoretical background is presented in section II, section III introduces research model and hypotheses, Section IV discusses research method. Section V presents discussions and Section VI concludes the paper. 


\section{THEORETICAL BACKGROUND}

Mobile technology has created several opportunities to enhance learning by providing a learning experience that is not limited by time and location [20] [21]. The increasing number of students owning mobile devices in universities has provided the opportunity of promoting mobile learning (m-learning). The authors in [21] define m-learning as learning that occurs when learners have access to information at anytime and anywhere through mobile technologies enabling them to perform activities that are authentic while learning. In [22], m-learning is define as a method of learning carried out in different contexts where learners may derive benefits from accessing learning materials through their smart mobile devices. Mobile learning applications provide students greater opportunity of using their mobile devices at anytime and anywhere to access resources for learning as well as other information that will support their education [23]. Buabeng-Andoh [15] proposed a hybrid model of theory of planned behaviour (TPB) and technology acceptance model (TAM) to explore factors that influenced the intention of students to use mobile learning in a university. The results showed that attitude had the most significant effect on students intention to use mobile learning. Qashou [19] studied factors that influenced m-learning adoption in higher education by using an extended TAM. The results showed that attitude to use and perceived usefulness were the most significant key factors that impacted on the intention of students to use mobile learning. The authors in [23] examined the effects of different factors that influences the acceptance of mobile learning applications by students in higher education. In their study, perceived compatibility, perceived information quality, perceived trust, self-efficacy, perceived awareness and availability of resources, and perceived security were the key factors that influences students acceptance of mobile learning system. Senaratne and Samarasinghe [20] studied factors that affects the intention to adopt mobile learning in Sri Lanka by extending TAM. In their findings, mobile self-efficacy, system quality and intrinsic motivation were the most significant determinants that influenced students intention to adopt m-learning in higher education in Sri Lanka. Chao [22] adopted extended unified theory of acceptance and use of technology (UTAUT) model to predict determinants that affects students behavioural intentions toward using mobile learning. The study showed that satisfaction is a key significant determinant that has effect on students behavioural intentions towards using m-learning. In addition, performance expectancy, trust and effort expectancy significantly have effect on students behavioural intentions towards using m-learning. Almaiah and Mulhem [24] found in their study that trust, relative advantage, quality of content, quality of service and quality of system have effect on the intention to use m-learning. Fatima et al. [25] adopted theory of planned behaviour in examining the behavioural adoption of m-learning that focuses on tourism education in Bangladesh. In their findings, subjective norms, perceived behavioural control and innovativeness have positive influence on attitude toward mobile learning thus leading to intention to adopt m-learning that focuses on tourism education. The authors in [26] examined quality factors and individual beliefs that influenced students satisfaction and their intention to use mobile learning system by using integrated TAM and updated DeLone and McLeans model. Their results indicated that quality factors such as quality of system, information and service have significant effect on the adoption of mobile learning system by students. In addition, individual beliefs such as perceived usefulness and perceived ease of use impacts students intention to use mobile learning system. Aburub and Alnawas [27] proposed hybrid model of key components of TAM and Usage and Gratification Approach in determining factors that influence adoption of mobile learning in higher education. In their study, perceived ease of use and cognitive gratification have the most significant effect on students intention to adopt mobile learning. Al-shihi et al. [28] developed a hybrid model of TAM and UTAUT and further used neural network to examine factors that impact students adoption of mobile learning in Oman. Their findings showed that economic learning, suitability learning, enjoyment learning, efficiency learning, flexibility learning, and social learning significantly influences students acceptance of mobile learning. Almaiah [29] investigated the adoption and use of mobile information system in a Jordan university. The findings showed that perceived security, perceived ease of use, trust and perceived usefulness significantly influenced students acceptance of mobile information system. Hamidi and Chavoshi [30] developed a model that examines the adoption of mobile learning application. In their findings, trust, quality of system, relative advantage, quality of content and quality of service significantly influenced students intention to use mobile learning. Pramana [31] conducted a study on determinants that influenced students adoption of mobile learning system in an Indonesian university. In their findings, perceived enjoyment and perceived usefulness were the two most significant determinants that influenced students adoption of mobile learning system.

Most of the previous studies used models such as TAM, UTAUT and TPB in examining determinants that influence adoption of mobile learning systems by students. However, most of these models were not developed specifically for the adoption of mobile technologies. In this study, mobile service acceptance model (MSAM) proposed by Gao et al. [32] was used to examine determinants that influence students adoption of mobile technology application in a university. The MSAM model was proposed to specifically examine adoption of mobile services and applications.

\section{RESEARCH MODEL AND HYPOTHESIS}

The authors in [32] proposed a mobile services acceptance model that specifically test the adoption of mobile services by end-users as shown in Fig. 1. Their proposed model is an extension of Technology Acceptance Model (TAM).

The model consists of context, personal initiatives and characteristics, trust, perceived ease of use, perceived usefulness and intention to use. Context describes the situation of entities that are deemed important to the interaction between an application and the enduser including both the application and the end-users [32].Personal initiatives and characteristics describes the willingness of the enduser to experiment with the new applications [32]. Trust describes the end-users faith or belief that a particular application can be considered as posing no privacy threats or security issues [32]. Perceived ease of use defines to what extent an end-user believes that using a specific system would be effortless [32]. Perceived usefulness defines the extent to which an end-user believes that using a specific system would improve his or her task [32]. Intention to use describes the likelihood of an end-user to interact with the mobile application [32].

\subsection{Research Hypotheses}

The research hypotheses were developed based on the mobile service acceptance model proposed by the authors in [32]. Seven hypotheses were proposed as shown in Fig. 1. 


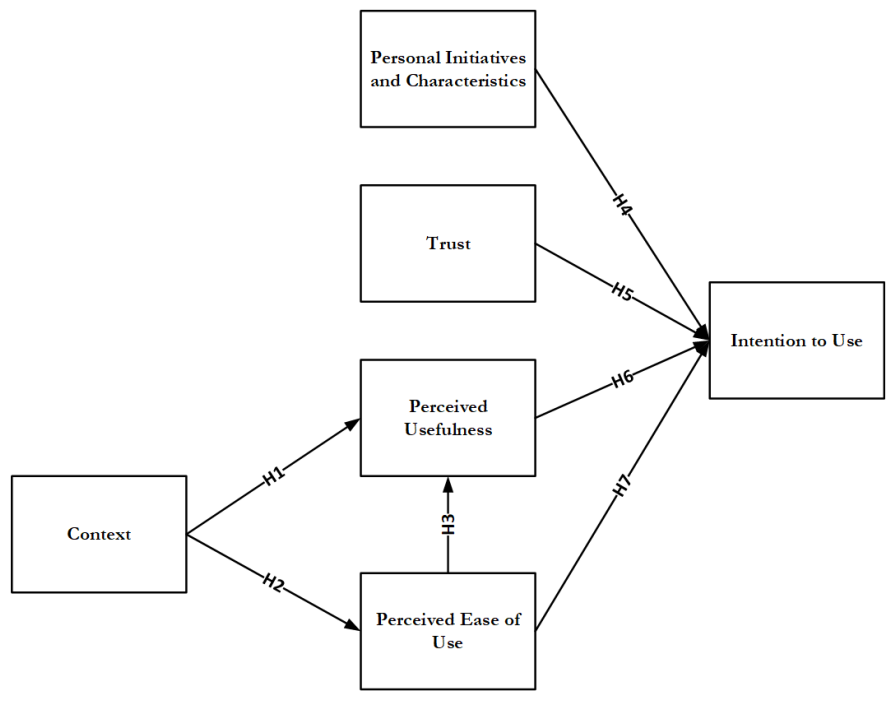

Fig. 1. Mobile Services Acceptance Model [32]

3.1.1 Context. Gao and Krogstie [33] posited that context is a significant factor that influences an adoption of mobile services by end-users. A mobile service will be viewed differently in various contexts in relation to the ease of use and its usefulness. The interest and expectations of an end-user differ with the context in which he/she uses a service, thus services that can address their requirements in a specific context can offer them the best value [34]. An end-user based on the context can take a decision on whether a mobile service is of use or not. The findings of the authors in [35] showed that the benefits and the usefulness of the mobile ticketing services were viewed differently in diverse use situations and that use situation has impact on the end-users intention to use such services. This study seeks to find out whether context directly affects perceived ease of use and perceived usefulness. Thus, the following hypotheses are proposed:

H1: The appropriate context of mobile technology positively has a direct effect on perceived usefulness of mobile technology.

H2: The appropriate context of mobile technology positively has a direct effect on perceived ease of use of a mobile technology.

3.1.2 Perceived Ease of Use: The authors in [26] [27] and [29] established that perceived ease of use had impact on students intention to use mobile learning. $\mathrm{Wu}$ and $\mathrm{Chen}[36]$ proposed the hybrid model of TAM and the task technology fit (TTF) model to investigate continuance intention to use the Massive Open Online Courses (MOOCs). In their findings, perceived ease of use was one of the key constructs that played a significant role in predicting continuance intention to use the MOOCs. Wu and Zhang [37] established that perceived ease of use is one of the key constructs that predicts continuance intention as well as the role of perceived ease of use in relation to perceived usefulness. The findings of $\mathrm{Lu}$ et al. [38], showed that perceived ease of use significantly influences users intention to try wireless internet services via mobile technology. Further, researches conducted by [39, 42] showed the significant effect perceived ease of use has on intention to use a technology, and its direct and indirect effects on perceived usefulness. Based on earlier research, the following hypotheses were proposed:

H3: Perceived ease of use of mobile technology has a direct effect on perceived usefulness of a mobile technology.

H7: Perceived ease of use of mobile technology has a direct effect on the intention to use a mobile technology.

3.1.3 Personal Initiative and Characteristics: Gao et al. [43], conducted a study to examine factors that influence adoption of mobile information services in a Norwegian university. In their work, it was shown that the most important factor that influences users intention to adopt mobile information services is the personal initiative and characteristics. Personal initiative and characteristics is considered as having the most significant effect among all factors on users intention to adopt mobile tourism services [44]. Earlier researches conducted by [38], [45] showed that personal innovativeness is a key factor that leads to acceptance of a technology by users. To keep in line with prior researches, this study expects a significant impact of personal initiative and characteristics on intention of users to use a technology, and thus hypothesize that:

H4: Personal initiatives and characteristics of a student has a direct effect on the intention to use a mobile technology.

3.1.4 Trust. Trust is considered as a significant construct that impacted on perceived ease of use and perceived usefulness [10]. In [13], the author seeks to study factors that may influence a consumers acceptance of making payments using mobile payment. The results in [13] showed that trust is one of the factors that influences a consumers intention to use mobile payment. Yaseen and Zayed [14] examined factors that will affect the intention to deploy mobile commerce technology. In their work, perceived trust is considered one of the critical determinants that had significant influence with intention to deploy mobile commerce technology. Furthermore, researchers [22] [23] [29] and [30] found that trust is one of the key determinants that influenced students adoption of mobile learning in higher education. The authors in [46] have shown that the end-users trust in a knowledge management systems (KMS) led to their intention to explore the KMS. Researches have shown the role of trust in influencing the intention of an end-user to adopt a technology. Thus, this study hypothesizes that:

H5: Trust has a direct effect on the intention to use a mobile technology.

3.1.5 Perceived Usefulness. The authors in [19] [26] [29] and $[31]$ indicated that perceived usefulness had effect on students acceptance of mobile learning. Furthermore, the authors in [36] showed that perceived usefulness is one of the key significant constructs that is critical to the continuance intention of users to use the MOOCs. The findings in |37 also indicated that perceived usefulness is an important construct that influences a users continuance intention towards the use of an E-Learning 2.0 system. Similarly, research conducted by [39.42] established that perceived usefulness has a direct effect on the intention of a user to use a technology. The findings of these studies indicate the importance of perceived usefulness on an end-users intention to adopt a technology. Thus, this study hypothesizes that:

H6: Perceived usefulness has a direct effect on the intention to use a mobile technology. 


\section{RESEARCH METHOD}

\subsection{Measurement Instrument}

The survey measure instrument proposed and validated by the authors in [47] was adopted to develop the survey measure instrument for this study. However, the adopted survey instrument measure adopted was slightly modified to suit this studys context based on the responses from a pilot test conducted with 30 respondents and feedback from experts who have knowledge in measurement instruments. The survey measure instrument has two major sections. The first section contains demographic questions about the respondents and the second section contains questions that measure constructs in the mobile service acceptance model. Five-point Likert scale instrument measure was used to examine students response to all items in the survey, with 1 indicating strongly disagree and 5 indicating strongly agree.

\subsection{Sampling procedure and data collection}

A total number of 170 students from Ho Technical University (HTU) participated in the experiment of using the HTU GPA mobile technology application that calculates the grade point average of students and determines their class division. The study used purposive sampling technique in selecting students. A paper-based survey was conducted after participants used the mobile technology application. Out of 170 respondents, there were 112 males representing $65.9 \%$ and 58 females representing $34.1 \%$. Table 1 provides the demographic profile of respondents.

\subsection{Data Analysis}

The PLS-SEM was used to analyze data collected from the survey. A two-step approach recommended by Chin [48] for evaluating structural equation modeling was used. Reliability and validity of the measurement model was first tested and subsequently the significance of hypothesized relationships among the constructs in the model was tested. The reliability and validity of the measurement model as well as hypothesized relationships among the constructs in the model were analyzed using SmartPLS version 3.

\subsection{Measurement model}

Reliability and validity assessment were carried out using Cronbachs Alpha coefficient, composite reliability (CR), average variance extracted (AVE) and Fornell-Larcker criterion. Internal consistency reliability of the measure model is measured using Cronbachs Alpha coefficient and CR. According to [49] a commonly agreed rule for Cronbach alpha is that a value of 0.6 to 0.7 indicates an acceptable level of reliability and a value of 0.8 or higher shows a very good level. However, values greater than 0.95 are regarded not necessarily good. From Table 2, Cronbach alpha coefficients for this study ranges from 0.601 to 0.813 . According to Hair et al. [50], composite reliability value of 0.6 to 0.7 is considered acceptable and values between 0.7 and 0.9 can be considered as satisfactory. From Table 2, CR values for this study ranges from 0.788 to 0.892 . A common measure of convergent validity is the AVE. AVE value of 0.5 or greater is regarded acceptable levels of AVE [50]. From Table 2, AVE values for this study ranges from 0.539 to 0.733 . Fornell-Larcker criterion was used to assess the models discriminant validity. Discriminant validity of the model is determined when the square root of each constructs AVE is greater than its highest correlation with any other construct [50]. Table 3 shows discriminant validity given by square root of the AVEs of each construct is greater than highest correlation with other con-

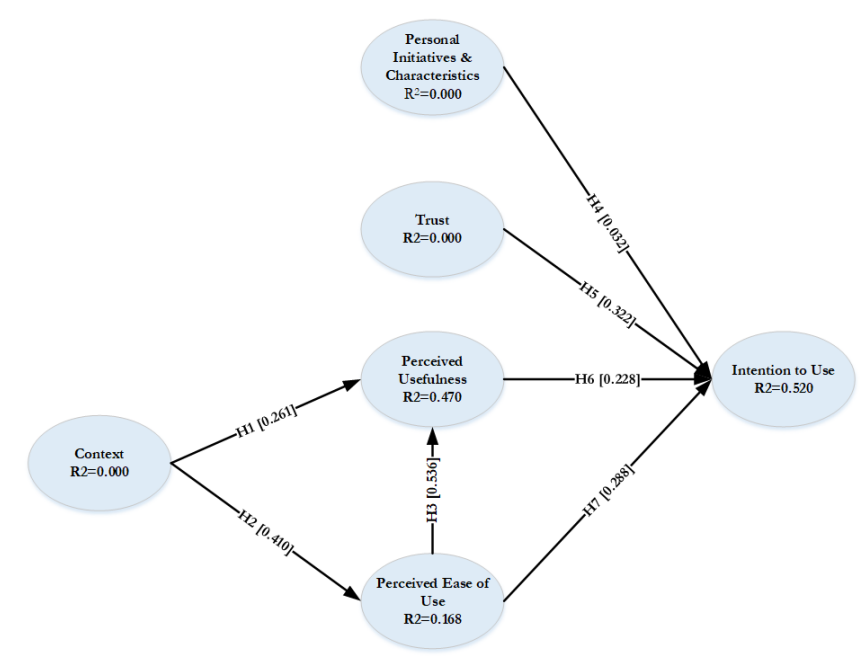

Fig. 2. Structural measurement model

structs (square root of AVEs are shown as the diagonal values). Table 2 shows reliability coefficient and validity for each of the constructs. It is evident from Table 2 and Table 3 that this measurement model is reliable and exhibits good convergent and discriminant validity.

\subsection{Structural Model}

The structural measurement model using PLS algorithm is presented in Figure 2. The significance of the path coefficient which represents standardized regression coefficient was tested. It was observed that context had a significant effect on both perceived usefulness and perceived ease of use $(\beta=0.261, p=0.00 ; \beta=0.410, p=0.00)$. Thus, providing support for $H 1$ and $H 2$. In providing support for $H 5$, Trust had the most significant effect on the intention to use $(\beta=0.536, p=0.00)$. In providing support for $H 5$, Trust was found to have the most significant effect on the intention to use $(\beta=0.322, p=0.00)$. Perceived ease of use is the second most important predictor of the intention to use $(\beta=0.288, p=0.00)$. Perceived Usefulness was found to have significant influence on the intention to use $(\beta=0.228, p=0.00)$. However, Personal initiatives and characteristics was found not to be a significant predictor of the intention to use $(\beta=0.032, p=0.89)$. Standardized root mean square residual (SRMR) is a model fit measure that was used to assess model fit. According to $\mathrm{Hu}$ and Bentler [51], SRMR value less than 0.08 is considered a good fit. The SRMR value is 0.07 which is less than 0.08 , thus the adopted model presents a good model fit. The structural model measurement results are presented in Table 4.

\section{DISCUSSION}

Research works have been carried out to examine determinants that influence the users adoption of a technology. However, there is little literature to examine determinants that will impact students adoption of a mobile technology. Thus, this research work provides both researchers and practitioners insights into determinants that have effect on students adoption of a mobile technology in a university. For researchers, this study contributes to existing literature on the adoption of a mobile technology while for practitioners it helps them gain a better insight into what key features to consider dur- 
Table 1. Demographic Profile of Respondents

\begin{tabular}{|c|c|c|c|}
\hline \multicolumn{2}{|l|}{ Variables } & Frequency & Percentage (\%) \\
\hline \multirow[t]{2}{*}{ Gender } & Male & 112 & 65.9 \\
\hline & Female & 58 & 34.1 \\
\hline \multirow[t]{4}{*}{ Age } & 20 and Below & 43 & 25.3 \\
\hline & $21-30$ & 119 & 70.0 \\
\hline & $31-40$ & 7 & 4.1 \\
\hline & $41-50$ & 1 & 0.6 \\
\hline \multirow[t]{4}{*}{ Faculty } & Faculty of Applied Sciences and Technology & 48 & 28.2 \\
\hline & Faculty of Engineering & 72 & 42.4 \\
\hline & HTU Business School & 10 & 5.9 \\
\hline & Faculty of Arts and Design & 40 & 23.5 \\
\hline \multirow[t]{4}{*}{ Educational Level } & Bachelor of Technology (BTech) & 2 & 1.2 \\
\hline & Higher National Diploma (HND) & 162 & 95.3 \\
\hline & Diploma in Business Studies (DBS) & 1 & 0.6 \\
\hline & Certificate & 5 & 2.9 \\
\hline \multirow[t]{3}{*}{ Experience in Mobile Application (Years) } & $0-3$ & 25 & 14.7 \\
\hline & $4-7$ & 76 & 44.7 \\
\hline & 8 and above & 69 & 40.6 \\
\hline
\end{tabular}

Table 2. Construct reliability and convergent validity

\begin{tabular}{|l|l|l|l|l|}
\hline Construct & $\begin{array}{l}\text { No. of } \\
\text { Items }\end{array}$ & $\begin{array}{l}\text { Cronbachs } \\
\text { Alpha }\end{array}$ & CR & AVE \\
\hline Context & 3 & 0.601 & 0.788 & 0.555 \\
\hline $\begin{array}{l}\text { Personal Initia- } \\
\text { tives \& Character- } \\
\text { istics }\end{array}$ & 0.712 & 0.823 & 0.539 \\
\hline Trust & 3 & 0.657 & 0.811 & 0.590 \\
\hline $\begin{array}{l}\text { Perceived Ease of } \\
\text { Use }\end{array}$ & 0.754 & 0.859 & 0.671 \\
\hline $\begin{array}{l}\text { Perceived Useful- } \\
\text { ness }\end{array}$ & 0.818 & 0.892 & 0.733 \\
\hline Intention to Use & 3 & 0.813 & 0.889 & 0.728 \\
\hline
\end{tabular}

Table 3. Discriminant validity

\begin{tabular}{|l|l|l|l|l|l|l|}
\hline & Context & $\begin{array}{l}\text { Intention } \\
\text { to Use }\end{array}$ & $\begin{array}{l}\text { Perceived } \\
\text { Ease of } \begin{array}{l}\text { Perceived } \\
\text { Useful- } \\
\text { ness }\end{array}\end{array}$ & $\begin{array}{l}\text { Personal } \\
\text { Initiatives } \\
\text { \& Char- } \\
\text { acteristics }\end{array}$ & Trust \\
\hline Context & $\mathbf{0 . 7 4 5}$ & & & & & \\
\hline $\begin{array}{l}\text { Intention } \\
\text { to Use }\end{array}$ & 0.402 & $\mathbf{0 . 8 5 3}$ & & & & \\
\hline $\begin{array}{l}\text { Perceived } \\
\text { Ease of } \\
\text { Use }\end{array}$ & 0.410 & 0.600 & $\mathbf{0 . 8 1 9}$ & & & \\
\hline $\begin{array}{l}\text { Perceived } \\
\text { Useful- } \\
\text { ness }\end{array}$ & 0.481 & 0.606 & 0.643 & $\mathbf{0 . 8 5 6}$ & & \\
\hline $\begin{array}{l}\text { Personal } \\
\text { Initiatives } \\
\& \text { Charac- } \\
\text { teristics }\end{array}$ & 0.545 & 0.538 & 0.553 & 0.640 & $\mathbf{0 . 7 3 4}$ & \\
\hline Trust & 0.516 & 0.596 & 0.458 & 0.535 & 0.624 & $\mathbf{0 . 7 3 4}$ \\
\hline
\end{tabular}

ing the design and development of mobile technologies.

In this study, trust was found to have the most important influence on the intention to use the HTU GPA mobile technology application as established in literature [10] [13] [14] [22] [23] [29] [30] and [46]. This implies that privacy and security are key issues that
Table 4. Path Coefficients and Hypotheses Results

\begin{tabular}{|c|c|c|c|c|c|}
\hline Hypotheses & Path & $\begin{array}{l}\text { Path coeffi- } \\
\text { cient }\end{array}$ & \begin{tabular}{|l|} 
T- \\
Statistics
\end{tabular} & P-Values & $\begin{array}{l}\text { Hypotheses } \\
\text { results }\end{array}$ \\
\hline H1 & \begin{tabular}{|l|} 
Context $->0$ \\
Perceived \\
Usefulness
\end{tabular} & $0.261 * * *$ & \begin{tabular}{|l|}
3.79 \\
\end{tabular} & 0.00 & Supported \\
\hline $\mathrm{H} 2$ & $\begin{array}{l}\text { Context }-> \\
\text { Perceived } \\
\text { Ease of Use }\end{array}$ & $0.410 * * *$ & 3.88 & 0.00 & Supported \\
\hline H3 & \begin{tabular}{|l|l} 
Perceived & \\
Ease of \\
Use $\quad->$ \\
Perceived \\
Usefulness \\
\end{tabular} & $0.536 * * *$ & 7.96 & 0.00 & Supported \\
\hline $\mathrm{H} 4$ & $\begin{array}{l}\text { Personal } \\
\text { Initiatives \& } \\
\text { Character- } \\
\text { istics - > } \\
\text { Intention of } \\
\text { Use }\end{array}$ & 0.032 & 0.13 & 0.89 & $\begin{array}{ll}\text { Not } & \text { sup- } \\
\text { ported } & \end{array}$ \\
\hline H5 & $\begin{array}{ll}\text { Trust } & -> \\
\text { Intention } & \text { of } \\
\text { Use } & \\
\end{array}$ & $0.322 * * *$ & 2.89 & 0.00 & Supported \\
\hline H6 & 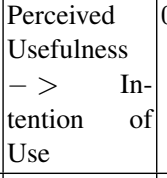 & $0.228 * * *$ & 2.96 & 0.00 & Supported \\
\hline H7 & $\begin{array}{|ll|}\text { Perceived } & \\
\text { Ease } & \text { of } \\
\text { Use } & -> \\
\text { Intention } & \text { of } \\
\text { Use } & \\
\end{array}$ & $0.288 * * *$ & 3.61 & 0.00 & Supported \\
\hline
\end{tabular}

influence the intention of students to use a mobile technology application. Thus, in developing mobile technologies for the use of students, practitioners must ensure that these technologies do not pose privacy or security issues to the students. Consistent with the 
findings of the authors in [19] |26] [29] [31] [36] [37] [39] [40] [41] and [42], the study found perceived usefulness to be a key predictor of the intention to use the HTU GPA mobile technology application. This suggests that students who have perceived that their academic performance would be improved using mobile technology application are likely to use the mobile technology application hence mobile technologies that will be deployed in the University setting must be developed and tailored towards students needs. In this study, the second most important determinant that had significant effect on students intention to use HTU GPA mobile technology application was perceived ease of use. This is consistent with prior research works in [26] [27] [29] [36] [37] [38] [39] [40] [41] and [42]. Implying, students who consider using the mobile technology application will be without much effort are likely to use the mobile technology application. Thus, it behooves on the industry players in mobile technologies to ensure that mobile technologies that are developed are not complex but rather easy to use. The study further found that context significantly affects perceived usefulness and perceived ease of use which indirectly affects the intention to use the HTU GPA mobile technology application. This finding is consistent with the results in [33] [35]. Contrary to the findings of research works in [43 44] this study did not find personal initiatives and characteristics as having any impact on the intention of students to use the HTU GPA mobile technology application. A possible reason may be that $85.3 \%$ students have some level of experience in mobile technology application for 4 years and above and probably experimenting with another kind of mobile technology application may not affect their intention to use this mobile technology application.

\section{CONCLUSION}

This study explored determinants that can influence students intention to use a mobile technology application in a Technical University. It adopted mobile service acceptance model as its research model; a model developed to explore mobile services adoption.

The findings from the study showed that trust, perceived usefulness and perceived ease of use are the key determinants of students intention to use the HTU GPA mobile technology application. Furthermore, context had significant impact on perceived usefulness and perceived ease of use and indirectly influenced students intention to use the mobile technology application.

Findings from this study have practical implications for practitioners during design and development of mobile technology application for use by students. Finally, this study contributes to literature on factors that influences students adoption of mobile technology application in a Ghanaian technical university and may be applicable to other students in higher education in Ghana.

\section{REFERENCES}

[1] K. Taylor and L. Silver, "Smartphone ownership is growing rapidly around the world, but not always equally," Pew Research Center, vol. 5, 2019.

[2] E. Dahlstrom and J. Bichsel, "Ecar study of undergraduate students and information technology, 2014." Educause, 2014.

[3] M. B. Kobus, P. Rietveld, and J. N. Van Ommeren, "Ownership versus on-campus use of mobile it devices by university students," Computers \& Education, vol. 68, pp. 29-41, 2013.

[4] H. Farley, A. Murphy, C. Johnson, B. Carter, M. Lane, W. Midgley, A. Hafeez-Baig, S. Dekeyser, and A. Koronios, "How do students use their mobile devices to support learn- ing? a case study from an australian regional university." Journal of Interactive Media in Education, vol. 2015, no. 1, 2015.

[5] A. Addo, "The adoption of mobile phone: how has it changed us socially?" Issues in Business Management and Economics, vol. 1, no. 3, pp. 47-60, 2013.

[6] M. A. Tagoe and E. Abakah, "Determining distance education students' readiness for mobile learning at university of ghana using the theory of planned behavior." International Journal of Education and Development using Information and Communication Technology, vol. 10, no. 1, pp. 91-106, 2014.

[7] J. K. Edumadze and N. A. Kuadey, "Studentsperception of mobile learning at university of cape coast, ghana," The Online Journal of Distance Education and e-Learning, vol. 7, no. 3, p. 226, 2019.

[8] S.-S. Liaw, M. Hatala, and H.-M. Huang, "Investigating acceptance toward mobile learning to assist individual knowledge management: Based on activity theory approach," Computers \& Education, vol. 54, no. 2, pp. 446-454, 2010.

[9] I. M. Al-Jabri and M. S. Sohail, "Mobile banking adoption: Application of diffusion of innovation theory," Journal of Electronic Commerce Research, vol. 13, no. 4, pp. 379-391, 2012.

[10] M. Reid and Y. Levy, "Integrating trust and computer selfefficacy with tam: An empirical assessment of customersã â â acceptance of banking information systems (bis) in jamaica," The Journal of Internet Banking and Commerce, vol. 13, no. 3, pp. 1-18, 1970.

[11] M.-I. R. M. Jaradat and A. M. Al-Mashaqba, "Understanding the adoption and usage of mobile paytowards an understanding of the consumer acceptance of mobile walletment services by using tam3," International Journal of Business Information Systems, vol. 16, no. 3, pp. 271-296, 2014.

[12] S. AlAwadhi and A. Morris, "The use of the utaut model in the adoption of e-government services in kuwait," in Proceedings of the 41st annual Hawaii international conference on system sciences (HICSS 2008). Ieee, 2008, pp. 219-219.

[13] D.-H. Shin, "Towards an understanding of the consumer acceptance of mobile wallet," Computers in Human Behavior, vol. 25, no. 6, pp. 1343-1354, 2009.

[14] S. G. Yaseen and S. Zayed, "Exploring determinants in deploying mobile commerce technology: Amman stock exchange," in 2010 International Conference on Information Society. IEEE, 2010, pp. 612-620.

[15] C. Buabeng-Andoh, "Exploring university students intention to use mobile learning: A research model approach," Education and information technologies, pp. 1-16, 2020.

[16] M. A. Almaiah, M. A. Jalil, and M. Man, "Preliminary study for exploring the major problems and activities of mobile learning system: A case study of jordan," 2016.

[17] M. Al-Emran, V. Mezhuyev, and A. Kamaludin, "Technology acceptance model in m-learning context: A systematic review," Computers \& Education, vol. 125, pp. 389-412, 2018.

[18] B. A. Kumar and S. S. Chand, "Mobile learning adoption: A systematic review," Education and Information Technologies, vol. 24, no. 1, pp. 471-487, 2019.

[19] A. Qashou, "Influencing factors in m-learning adoption in higher education," Education and Information Technologies, pp. 1-31, 2020. 
[20] S. I. Senaratne, S. M. Samarasinghe, and G. Jayewardenepura, "Factors affecting the intention to adopt m-learning," Int. Bus. Res, vol. 12, no. 2, p. 150, 2019.

[21] F. Martin and J. Ertzberger, "Here and now mobile learning: An experimental study on the use of mobile technology," Computers \& Education, vol. 68, pp. 76-85, 2013.

[22] C.-M. Chao, "Factors determining the behavioral intention to use mobile learning: An application and extension of the utaut model," Frontiers in psychology, vol. 10, p. 1652, 2019.

[23] M. A. Almaiah, M. M. Alamri, and W. Al-Rahmi, "Applying the utaut model to explain the students acceptance of mobile learning system in higher education," IEEE Access, vol. 7, pp. 174 673-174 686, 2019.

[24] M. A. Almaiah and A. Al Mulhem, "Analysis of the essential factors affecting of intention to use of mobile learning applications: A comparison between universities adopters and nonadopters," Education and Information Technologies, vol. 24, no. 2, pp. 1433-1468, 2019.

[25] J. K. Fatima, P. Ghandforoush, M. Khan, and R. D. Mascio, "Mobile learning adoption for tourism education in a developing country," Current issues in Tourism, vol. 22, no. 4, pp. 420-427, 2019.

[26] M. A. Almaiah and O. A. Alismaiel, "Examination of factors influencing the use of mobile learning system: An empirical study," Education and Information Technologies, vol. 24, no. 1, pp. 885-909, 2019.

[27] F. Aburub and I. Alnawas, "A new integrated model to explore factors that influence adoption of mobile learning in higher education: An empirical investigation," Education and Information Technologies, vol. 24, no. 3, pp. 2145-2158, 2019.

[28] H. Al-Shihi, S. K. Sharma, and M. Sarrab, "Neural network approach to predict mobile learning acceptance," Education and Information Technologies, vol. 23, no. 5, pp. 1805-1824, 2018.

[29] M. A. Almaiah, "Acceptance and usage of a mobile information system services in university of jordan," Education and Information Technologies, vol. 23, no. 5, pp. 1873-1895, 2018.

[30] H. Hamidi and A. Chavoshi, "Analysis of the essential factors for the adoption of mobile learning in higher education: A case study of students of the university of technology," Telematics and Informatics, vol. 35, no. 4, pp. 1053-1070, 2018.

[31] E. Pramana, "Determinants of the adoption of mobile learning systems among university students in indonesia," Journal of Information Technology Education: Research, vol. 17, pp. 365-398, 2018.

[32] S. Gao, J. Krogstie, and P. A. Gransæther, "Mobile services acceptance model," in 2008 International Conference on Convergence and Hybrid Information Technology. IEEE, 2008, pp. $446-453$.

[33] S. Gao and J. Krogstie, "The importance of context towards mobile services adoption," in The Fourth International Conference on Mobile Ubiquitous Computing, Systems, Services and Technologies (Ubicomm 2010), 2010.

[34] S. Figge, "Situation-dependent servicesa challenge for mobile network operators," Journal of Business Research, vol. 57, no. 12, pp. 1416-1422, 2004.

[35] N. Mallat, M. Rossi, V. K. Tuunainen, and A. Oorni, "The impact of use situation and mobility on the acceptance of mobile ticketing services," in Proceedings of the 39th Annual Hawaii International Conference on System Sciences (HICSS'06), vol. 2. IEEE, 2006, pp. 42b-42b.

[36] B. Wu and X. Chen, "Continuance intention to use moocs: Integrating the technology acceptance model (tam) and task technology fit (ttf) model," Computers in Human Behavior, vol. 67 , pp. 221-232, 2017.

[37] B. Wu and C. Zhang, "Empirical study on continuance intentions towards e-learning 2.0 systems," Behaviour \& Information Technology, vol. 33, no. 10, pp. 1027-1038, 2014.

[38] J. Lu, J. E. Yao, and C.-S. Yu, "Personal innovativeness, social influences and adoption of wireless internet services via mobile technology," The Journal of Strategic Information Systems, vol. 14, no. 3, pp. 245-268, 2005.

[39] F. D. Davis, "Perceived usefulness, perceived ease of use, and user acceptance of information technology," MIS quarterly, pp. 319-340, 1989.

[40] C. M. Jackson, S. Chow, and R. A. Leitch, "Toward an understanding of the behavioral intention to use an information system," Decision sciences, vol. 28, no. 2, pp. 357-389, 1997.

[41] R. Agarwal and J. Prasad, "Are individual differences germane to the acceptance of new information technologies?" Decision sciences, vol. 30, no. 2, pp. 361-391, 1999.

[42] V. Venkatesh, "Creation of favorable user perceptions: Exploring the role of intrinsic motivation," MIS quarterly, pp. 239-260, 1999.

[43] S. Gao, J. Krogstie, M. Asif, and N. Kuadey, "An empirical study of mobile information services adoption at a norwegian university," in International Conference on Electronic Business, Shanghai, China, 2010.

[44] S. Gao, P. C. Røinend, and J. Krogstie, "The adoption of mobile tourism services: an empirical study," in Proceedings of the 10th International Conference on Advances in Mobile Computing \& Multimedia, 2012, pp. 47-56.

[45] R. Agarwal and J. Prasad, "A conceptual and operational definition of personal innovativeness in the domain of information technology," Information systems research, vol. 9, no. 2, pp. 204-215, 1998.

[46] J. B. Thatcher, D. H. McKnight, E. W. Baker, R. E. Arsal, and N. H. Roberts, "The role of trust in postadoption it exploration: An empirical examination of knowledge management systems," IEEE Transactions on Engineering Management, vol. 58, no. 1, pp. 56-70, 2010.

[47] S. Gao, J. Krogstie, and K. Siau, "Developing an instrument to measure the adoption of mobile services," Mobile information systems, vol. 7, no. 1, pp. 45-67, 2011.

[48] W. W. Chin et al., "The partial least squares approach to structural equation modeling," Modern methods for business research, vol. 295, no. 2, pp. 295-336, 1998.

[49] G. Ursachi, I. A. Horodnic, and A. Zait, "How reliable are measurement scales? external factors with indirect influence on reliability estimators," Procedia Economics and Finance, vol. 20, pp. 679-686, 2015.

[50] J. F. Hair Jr, G. T. M. Hult, C. Ringle, and M. Sarstedt, $A$ primer on partial least squares structural equation modeling (PLS-SEM). Sage publications, 2016.

[51] L.-t. Hu and P. M. Bentler, "Cutoff criteria for fit indexes in covariance structure analysis: Conventional criteria versus new alternatives," Structural equation modeling: a multidisciplinary journal, vol. 6, no. 1, pp. 1-55, 1999. 